\title{
The Effect of Feedwater Heaters Operation Schemes to a 200 MW Steam Power Plant Heat Rate Using Cycle-Tempo Software
}

\author{
Adi Apriyanto Wijaya ${ }^{1}$, Budi Utomo Kukuh Widodo²
}

\begin{abstract}
There are several ways to improve performance of Rankine cycle which is implemented at steam power plant, regenerative feedwater heating is one of the methods. Some failures in closed feedwater heaters such as, water leak through manhole and tube leakage may happen during operation of the plant. Repairing such failures may take some period of time and must shut off the operation of the feedwater heaters. Further study is needed to evaluate the effect of closed feedwater heater in off-service condition against the steam power plant's performance. This study varies off-service condition of closed feedwater heaters applying thermodynamics analysis and modeled through Cycle-Tempo software. There are 12 possible feedwater heater operation schemes. Based on the heat balance and equipment design of a $200 \mathrm{MW}$ Steam Power Plant at Jakarta-Indonesia, this study concluded that the NPHR might increase as much as $0.96 \%$ and $0.39 \%$ due to the off-service of any HPH and the offservice of any LPH respectively. Schemes of 2 off-service feedwater heaters summed up with $1.37 \%$ increase of NPHR.
\end{abstract}

Keywords_-Feedwater Heater, Cycle-Tempo, Steam Power Plant, Net Plant Heat Rate

\section{INTRODUCTION}

$\mathrm{T}$ he utilization of electricity is always increased from year to year and steam power plants are widely utilized throughout the world for electricity generation. In order to achieve the maximum utilization of energy resources and performance of the plant, researchers have the great interest on thermodynamics analysis of the power plant. There are a lot of techniques applied to increase the performance of the steam power cycle, one of them is regenerative feedwater heating. The changes in thermal efficiency that resulting from cycle modifications are already analyzed by [1]. By adding either open feedwater heaters and/or closed feedwater heaters, the efficiency of the cycle will increase [2]. This is due to the raise of the mean feedwater temperature at the boiler inlet which is heated by the extraction steam. The study [3] has been done to determine the effect of the number of closed feedwater heaters installed in a steam power plant. For a single feedwater heater, the efficiency is maximized at a bled steam temperature ratio of 0.4 . In general, the efficiency of the cycle is optimum at the reheater pressure of $20-25 \%$ of the boiler pressure. Similarly, the results of the study [4] mentioned that the efficiency of a regenerative cycle may increase along with the increase of feedwater heater numbers, and the temperature of evaporator and superheater. Numerous researchers have used software to simulate and optimize vapor power cycle performance.

\footnotetext{
${ }^{1}$ Adi Apriyanto Wijaya is with Business Development Unit, Pembangkitan Jawa Bali Company, Jakarta, Indonesia. E-mail: adi,apriyanto@ptpjb.com.

${ }^{2}$ Budi Utomo Kukuh Widodo is with Departement of Mechanical Engineering, Institut Teknologi Sepuluh Nopember, Surabaya, 60111, Indonesia. E-mail: buditem@me.its.ac.id.
}

The cycle-tempo software has been known as a program to perform thermodynamic modeling and system optimization for electricity production [5]. It was reported by [6] that modelling and simulating has been conducted to a coal power plant with a capacity of $62.5 \mathrm{MW}$ to obtain maximum efficiency value of the power plant using cycletempo software. Also energy and exergy analysis of a coal based thermal power plant studied by [7] using Cycletempo. In a certain amount of mass extraction flow from the turbine to the feedwater heater will increase the efficiency of power plant, however it could also decrease the efficiency if excessive steam is extracted. Extraction steam will reduce the performance of the turbine because the main function of the steam to turn the turbine blades is not achieved optimally. It is in turn will decrease the plant efficiency.

\section{METHOD}

This study is to determine the effect of feedwater heaters off-service condition to the performance of the steam power plant using thermodynamics analysis and Cycle-Tempo simulation. Heat balance data and equipment specification are used for baseline of modeling (Figure 1). In order to validate the model, the actual performance test result is presented as benchmark (Table 2). The model is then validated by the maximum allowable flow rate of extracted steam to each heater (Table 3). There are 5 closed feedwater heaters in the system consist of 3 Low Pressure Heaters (LPH) and 2 high pressure heaters. Therefore, the simulation has 12 variations of heaters off-service condition as shown in Table 1.

\section{A. Thermodynamic Analysis}

Closed feedwater heater is commonly used in regenerative Rankine cycle to improve cycle performance. 
In Closed Feedwater Heater, heat is transferred from the extraction steam to the feedwater without direct contact between the two fluids so that the two fluids can have different pressures. In an ideal Closed Feedwater Heater, the steam extracted from the turbine will exit the heater in a saturated liquid form at said vapor pressure. In a powergenerating system, the feedwater leaves the heater below the exit temperature of the extraction vapor because a temperature difference of several degrees is required for the effectiveness of heat transfer.

TABLE 1.

FEEDWATER HEATERS VARIATION

\begin{tabular}{cl}
\hline \hline Variation & \multicolumn{1}{c}{ Feedwater heaters operating condition } \\
\hline 1 & All heaters on-service \\
2 & LPH A off-service, others on-service \\
3 & LPH B off-service, others on-service \\
4 & LPH C off-service, others on-service \\
5 & HPH E off-service, others on-service \\
6 & HPH F off-service, others on-service \\
7 & LPH A \& HPH E off-service, others on-service \\
8 & LPH B \& HPH E off-service, others on-service \\
9 & LPH C \& HPH E off-service, others on-service \\
10 & LPH A \& HPH F off-service, others on-service \\
11 & LPH B \& HPH F off-service, others on-service \\
12 & LPH C \& HPH F off-service, others on-service \\
\hline \hline
\end{tabular}

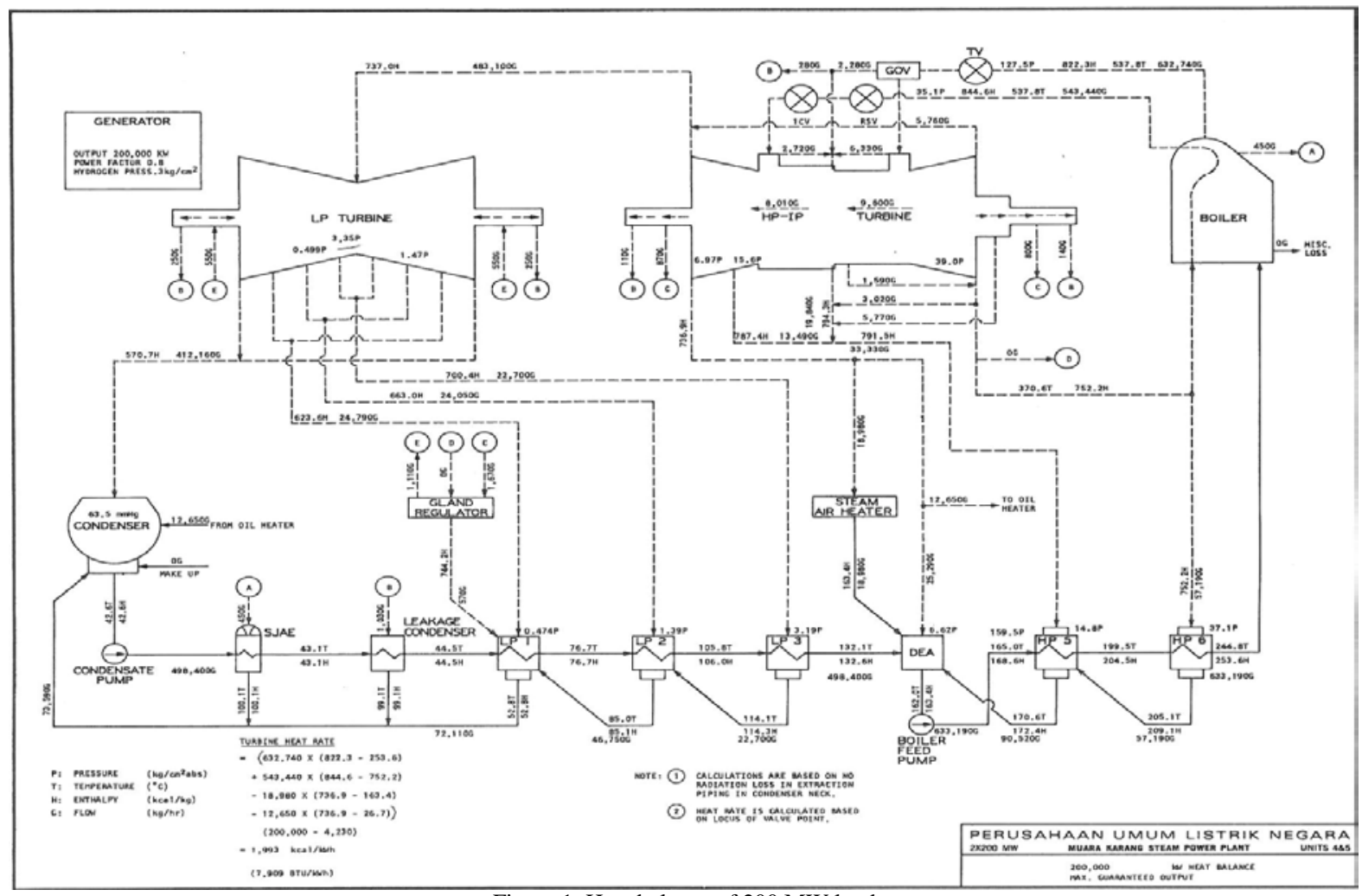

Figure 1. Heat balance of $200 \mathrm{MW}$ load

Based on Figure 2, total work of turbine per unit of steam While the pump work is: mass flow is:

$$
\frac{\dot{W}_{t}}{\dot{m}_{1}}=\left(h_{1}-h_{2}\right)+(1-y)\left(h_{2}-h_{3}\right)
$$

$$
\frac{\dot{W}_{p}}{\dot{m}_{1}}=\left(h_{5}-h_{4}\right)
$$


The energy added to the working fluid per unit of steam mass flow through heat transfer in the boiler is:

$$
\frac{\dot{Q}_{i n}}{\dot{m}_{1}}=\left(h_{1}-h_{6}\right)
$$

In general, the heat rate is defined as the total heat input into a plant divided by the total power generated by the plant, in $\mathrm{Btu} / \mathrm{kWh}$ or $\mathrm{kJ} / \mathrm{kWh}$ or $\mathrm{kCal} / \mathrm{kWh}$. The greater the value of the heat rate indicates that the performance of the power plant is lower and vice versa. Direct method is one of heat rate testing/calculation method to determine heat rate of the cycle.

The calculation of Net Plant Heat Rate (NPHR) with this method can be done through the equation as follows:

$$
N P H R=\frac{M_{\text {fuel }} \cdot \text { HHV }}{P_{\text {gen }}-P_{\text {aux }}}=\frac{Q_{\text {in boiler }}}{\text { Pgen-Paux. }}
$$

$0.39 \%$ higher than that of normal condition. For variation 6 (HPH F off), the NPHR will raise to $2.513 \mathrm{kCal} / \mathrm{kWh}$ or about $0.96 \%$ higher than that of normal condition. For variation 12 (LPH C and HPH F off), the NPHR will increase to $2,523 \mathrm{kCal} / \mathrm{kWh}$ or $1.37 \%$ higher than that of normal condition.

It is also known that HPH F has the greatest influence on the performance of power plant if it is off-service. It is due to the extraction steam to HPH F having the highest energy flow among other heaters that is $49.639 .08 \mathrm{~kJ} / \mathrm{s}$ according to Table 5. The highest increasing in feedwater temperature $\left(45.3^{\circ} \mathrm{C}\right)$ also occurs in HPH F. If HPH F is off-service then the boiler will require more thermal energy to overcome the temperature increase that should occur in the HPH F. Table 5 also shows that when HPH $F$ is off-service, the heat required by the boiler to increase the feedwater temperature is $557,112.38 \mathrm{~kJ} / \mathrm{s}$ or increased.

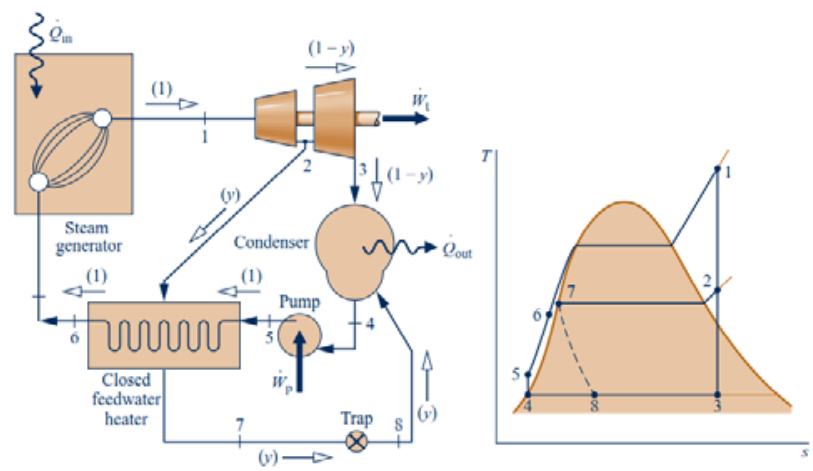

Figure 2. Regenerative Rankine cycle with closed feedwater heater

\section{B. Cycle-Tempo Simulation}

The Cycle-Tempo simulation is based on heat balance data on 200 MW (Figure 1) and performance test result of actual operation (Table 2). The modeling result is shown on Fig. 3 below. This modeling then used as a baseline for varying heater operating schemes. All variation models are then evaluated in accordance with the requirements in the design specifications of mass flow rate in Table 3.

Evaluation result for all variations then displayed in Table 4. Some variations must be rejected due to mass flow rate on those heaters are above the maximum allowable flow rate. After evaluated, there are only 4 variations of operating schemes that meet the requirements, i.e variations no. 1, 4, 6 and 12. These variations are then analyzed for their impact on the performance of the steam power plant.

\section{RESUltS AND DisCUSSION}

Figure 4 exhibits the result of NPHR for each operating schemes. It is shown that there is an increase on NPHR if either LPH or HPH are off-service. For variation 4 (LPH C off), the NPHR will increase to $2,499 \mathrm{kCal} / \mathrm{kWH}$ or $0.39 \%$ higher than that of normal condition. For variation 6 (HPH $\mathrm{F}$ off), the NPHR will raise to $2.513 \mathrm{kCal} / \mathrm{kWh}$ or about $0.96 \%$ higher than that of normal condition. For variation 12 (LPH C and HPH F off), the NPHR will increase to $2,523 \mathrm{kCal} / \mathrm{kWh}$ or $1.37 \%$ higher than that of normal condition.

It is also known that HPH F has the greatest influence on the performance of power plant if it is off-service. It is due to the extraction steam to HPH F having the highest energy flow among other heaters that is $49.639 .08 \mathrm{~kJ} / \mathrm{s}$ according to Table 5. The highest increasing in feedwater temperature $\left(45.3^{\circ} \mathrm{C}\right)$ also occurs in HPH F. If HPH F is off-service then the boiler will require more thermal energy to overcome the temperature increase that should occur in the HPH F. Table 5 also shows that when HPH $F$ is off-service, the heat required by the boiler to increase the feedwater temperature is $557,112.38 \mathrm{~kJ} / \mathrm{s}$ or increased by $6,553.07 \mathrm{~kJ} / \mathrm{s}$ from conditions where all heaters on-service.

\section{CONCLUSION}

Thermodynamic analysis and simulation of a $200 \mathrm{MW}$ steam power plant has been performed under different operating condition of closed feedwater heaters, the following insight into the cycle performance have been acquired:

- Based on evaluation of all variation schemes, there are only 4 variation schemes that meet the requirement i.e. variation no.1 (All heaters on), no.4 (LPH C off), 6 (HPH F off) and 12 (LPH C \& HPH F off).

- NPHR might increase as much as $0.96 \%$ and $0.39 \%$ due to the off-service of any HPH and the off-service of any $\mathrm{LPH}$ respectively. Schemes of 2 off-service feedwater heaters summed up with $1.37 \%$ increase of NPHR.

- HPH F has the greatest influence on the performance power plant because the highest increasing feedwater temperature occurs in HPH F.

TABLE 2.

ACTUAL PERFORMANCE TEST RESULT OF 200 MW LOAD

\begin{tabular}{lcccccccccc}
\hline \multirow{2}{*}{ Item } & \multirow{2}{*}{ Units } & \multicolumn{8}{c}{ Performance Test Result Data } \\
\cline { 3 - 12 } & & $\mathbf{1}$ & $\mathbf{2}$ & $\mathbf{3}$ & $\mathbf{4}$ & $\mathbf{5}$ & $\mathbf{6}$ & $\mathbf{7}$ & $\mathbf{8}$ & Average \\
\hline Gen. load & {$[\mathrm{MW}]$} & 199.5 & 200.8 & 200.8 & 195.8 & 200.6 & 200.6 & 200.8 & 200.8 & 199.96 \\
Steam Flow & {$[\mathrm{kg} / \mathrm{s}]$} & 190.9 & 172.2 & 172.2 & 163.2 & 171.6 & 172.8 & 173.5 & 176.1 & 174.05
\end{tabular}




\begin{tabular}{lllllllllll} 
Boiler eff. & {$[\%]$} & 89.61 & 85.24 & 84.92 & 85.36 & 85.07 & 86.63 & 86.82 & 86.48 & 86.27 \\
Turbine eff. & {$[\%]$} & 89.57 & 92.29 & 91.18 & 90.01 & 92.63 & 92.57 & 92.51 & 89.33 & 91.26 \\
NPHR & {$[\mathrm{kCal} / \mathrm{kWh}]$} & 2472 & 2461 & 2439 & 2499 & 2476 & 2534 & 2512 & 2520 & 2489 \\
\hline \hline
\end{tabular}

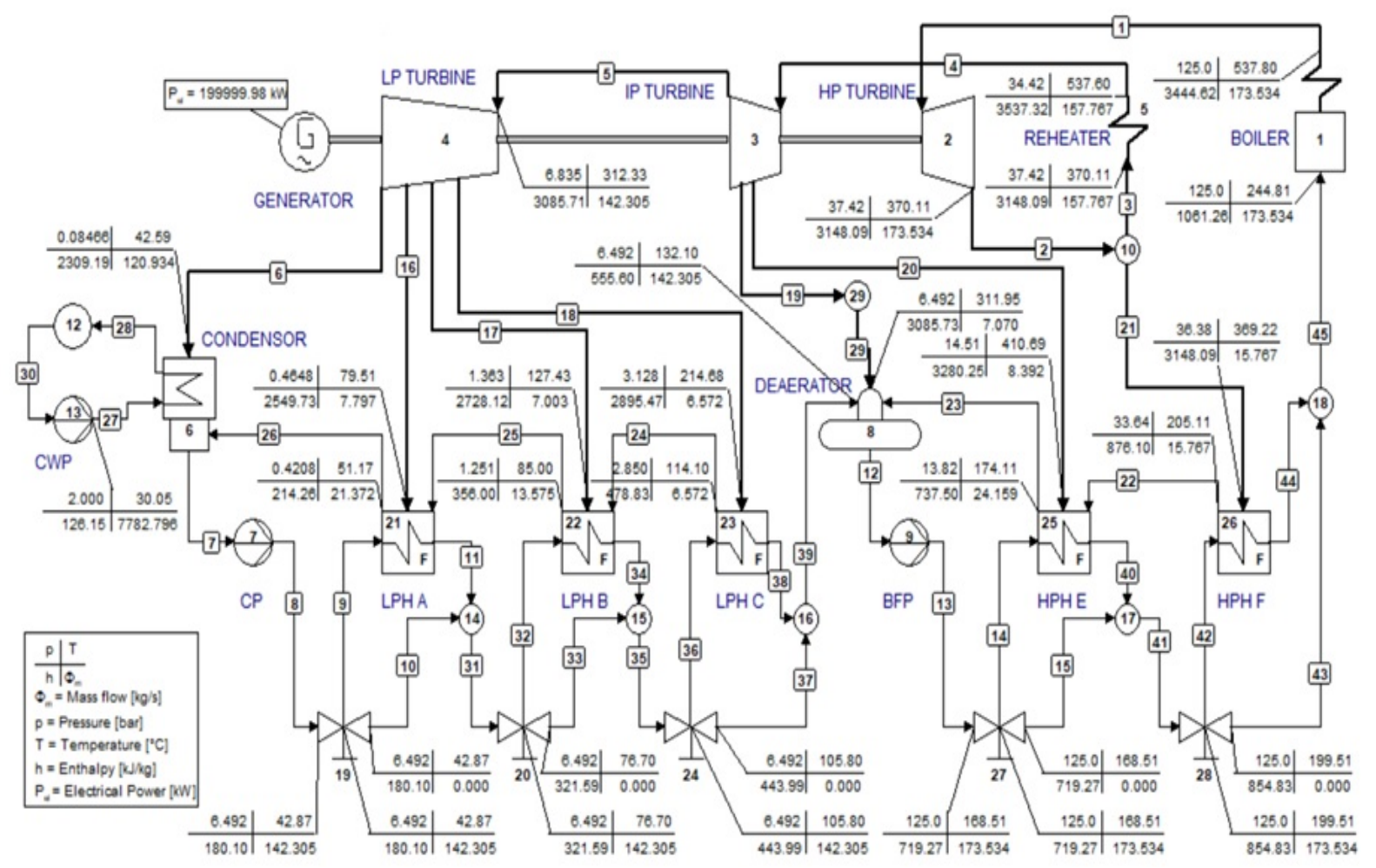

Figure 3. Cycle-Tempo simulation on 200 MW load - Variation 1.

TABLE 3.

DESIGN MASS FLOW RATE OF EACH HEATER

\begin{tabular}{ccc}
\hline & DESIGN MASS FLOW RATE OF EACH HEATER \\
\hline \hline Heater & Feedwater Flow (kg/s) & Steam \& Drain Flow $\mathbf{( k g / s )}$ \\
\hline LPH A & 156.94 & 28.12 \\
LPH B & 156.94 & 18.02 \\
LPH C & 156.94 & 8.79 \\
Deaerator & 180.56 & 194.06 \\
HPH E & 190.28 & 28.19 \\
HPH F & 190.28 & 18.06 \\
\hline \hline
\end{tabular}

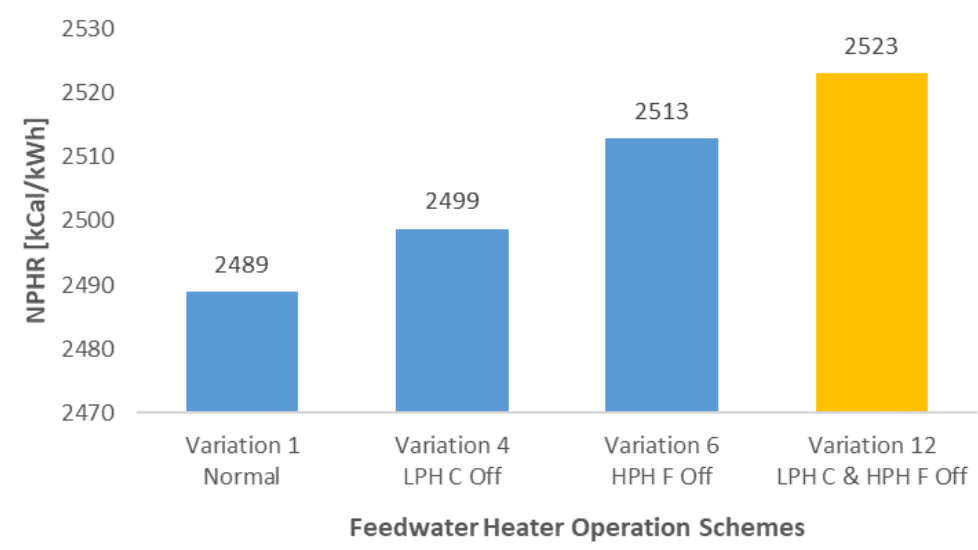

Figure 4. Graph of NPHR based on Cycle-Tempo simulation 
TABLE 4.

EVALUATION RESULT OF EACH HEATER BASED ON EXTRACTION STEAM \& DRAIN MASS FLOW RATE

\begin{tabular}{ccccccccc}
\hline \hline \multirow{2}{*}{ Variation } & \multicolumn{7}{c}{ Extraction Steam \& Drain Mass Flow Rate [kg/s] } & \multirow{2}{*}{ Condition } \\
\cline { 2 - 6 } & LPH A & LPH B & LPH C & Deaerator & HPH E & HPH E & HPH F & \\
\hline 1 & 21.55 & 13.58 & 6.57 & 173.53 & 24.16 & 15.77 & Accept & - \\
2 & 0.00 & 20.93 & 6.61 & 174.44 & 24.29 & 15.85 & Reject & LPH B Overflow \\
3 & 21.03 & 0.00 & 13.17 & 174.24 & 24.26 & 15.83 & Reject & LPH C Overflow \\
4 & 14.92 & 7.06 & 0.00 & 174.19 & 24.25 & 15.83 & Accept & - \\
5 & 21.56 & 13.7 & 6.63 & 175.65 & 0.00 & 24.93 & Reject & HPH F Overflow \\
6 & 21.80 & 13.85 & 6.70 & 161.34 & 8.60 & 0.00 & Accept & - \\
7 & 0.00 & 14.45 & 6.67 & 176.99 & 0.00 & 25.06 & Reject & HPH F Overflow \\
8 & 21.22 & 0.00 & 13.29 & 176.38 & 0.00 & 25.03 & Reject & LPH C \& LPH F Overflow \\
9 & 15.06 & 7.12 & 0.00 & 176.32 & 0.00 & 25.02 & Reject & HPH F Overflow \\
10 & 0.00 & 21.53 & 6.74 & 162.20 & 8.65 & 0.00 & Reject & LPH B Overflow \\
11 & 21.45 & 0.00 & 13.34 & 162.01 & 8.64 & 0.00 & Reject & LPH C Overflow \\
12 & 15.22 & 7.2 & 0.00 & 161.96 & 8.63 & 0.00 & Accept & - \\
MAX & 28.22 & 18.02 & 8.79 & 194.06 & 28.19 & 18.06 & & \\
\hline \hline
\end{tabular}

TABLE 5.

EXTRACTION STEAM AND FEEDWATER PROPERTIES AT NORMAL OPERATION LOAD 200 MW

\begin{tabular}{|c|c|c|c|c|c|c|c|}
\hline \multirow[b]{2}{*}{ Heater } & \multicolumn{3}{|c|}{ Extraction Steam } & \multicolumn{3}{|c|}{ Condensate / Feed Water } & \multirow[b]{2}{*}{$\begin{array}{l}\text { Heat absorbed by boiler } \\
\text { when heater not operated }\end{array}$} \\
\hline & $\begin{array}{l}\text { Flow } \\
\text { Rate } \\
\text { (kg/s) }\end{array}$ & $\begin{array}{l}\text { Enthalphy } \\
(\mathrm{kJ} / \mathrm{kg})\end{array}$ & $\begin{array}{l}\text { Energy } \\
(\mathrm{kJ} / \mathrm{s})\end{array}$ & $\begin{array}{l}\text { Inlet } \\
\text { Temp. }\left({ }^{\circ} \mathrm{C}\right)\end{array}$ & $\begin{array}{l}\text { Outlet Temp. } \\
\left({ }^{\circ} \mathrm{C}\right)\end{array}$ & $\begin{array}{l}\text { Temp. } \\
\text { Increased }\left({ }^{\circ} \mathrm{C}\right)\end{array}$ & \\
\hline LPH A & 7,80 & $2.546,73$ & $19.880,24$ & 42,87 & 76,70 & 33,83 & $555.477,88$ \\
\hline LPH B & 7,00 & $2.728,12$ & $19.105,02$ & 76,70 & 105,80 & 29,10 & $553.329,62$ \\
\hline LPH C & 6,57 & $2.895,47$ & $19.029,03$ & 105,80 & 132,10 & 26,30 & $552.672,38$ \\
\hline HPH E & 8,39 & $3.280,25$ & $27.524,58$ & 168,51 & 199,51 & 31,00 & $553.236,56$ \\
\hline \multirow[t]{2}{*}{ HPH F } & 15,77 & $6.148,09$ & 49.639,08 & 199,51 & 244,81 & 45,30 & $557.112,38$ \\
\hline & & & & \multicolumn{3}{|c|}{ Normal Operation } & $550.559,31$ \\
\hline
\end{tabular}

\section{REFERENCES}

[1] M. J. Moran and H. N. Saphiro, Fundamentals of Engineering Thermodynamics. Chichester: John Wiley \& Sons Inc, 2011.

[2] ASIMPTOTE, Cycle-tempo manual reference guide. HeeswijkDinther, Netherlands: ASIMPTOTE.

[3] Black \& Veatch International Consulting Engineers, "Muara karang steam power plant units 4 and 5 operating instructions," 1979.

[4] Y. A. Çengel and M. A. Boles, Thermodynamics : an engineering approach, 8. ed. New York: McGraw-Hill, 2015.
[5] F. P. Incropera, D. P. DeWitt, T. L. Bergman, and A. S. Lavine, Fundamentals of heat and mass transfer., 6th ed. Danvers (MA): John Wiley \& Sons, 2007.

[6] J. H. Horlock, "Simplified analysis of some vapor power cycles," Proc. Inst. Mech. Eng. Part A J. Power Energy, vol. 210, no. 3, pp. 191-202, Jun. 1996.

[7] T. Srinivas, A. V. S. S. K. S. Gupta, and B. V Reddy, "Generalized Thermodynamic Analysis of Steam Power Cycles with ' $n$ ' Number of Feedwater Heaters,” Int. J. Thermodyn., vol. 10, no. 4, pp. 177185, 2007. 